\title{
How "Chicagoan" are Gary Becker's Economic Models of Marriage?
}

\author{
SHOSHANA GROSSBARD
}

\author{
CESIFO WORKING PAPER NO. 2637 \\ CATEGORY 12: EMPIRICAL AND THEORETICAL METHODS \\ MAY 2009
}
An electronic version of the paper may be downloaded
- from the SSRN website: www.SSRN.com
- from the RePEc website:
- from the CESifo website:




\title{
How "Chicagoan" are Gary Becker's Economic Models of Marriage?
}

\begin{abstract}
This paper describes Gary Becker's theoretical models of marriage. At the micro-level, these are all rational choice models. At the market level, Becker offers two major types of models: partial equilibrium models based on Price Theory as taught by Marshall and Friedman and optimal sorting models based on optimal assignment models. The paper examines some of the possible intellectual influences on Becker's theory of marriage, compares Becker's research on marriage with that of some scholars interested in intra-marriage distribution, and documents that Becker's students at Chicago were more interested in Becker's Friedmanian models of marriage than in his optimal assignment models.
\end{abstract}

JEL Code: J12.

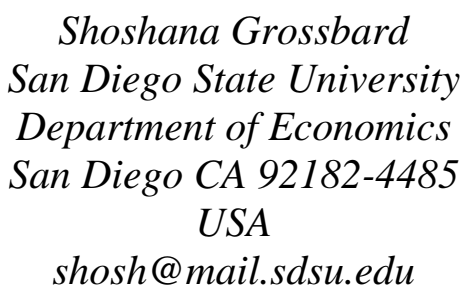

February 22, 2009

An earlier version of this paper, "The Shrinking Role of Demand and Supply Models in Gary Becker's Theories of Marriage," was presented at the University of Florida at Gainesville in 2004. I thank the following for helpful comments and advice: this journal's editors, anonymous referees, Gary Becker, William A. Brock, Scott Drewianka, Valerio Filoso, Joel Guttman, Sarah Hamersma, Lawrence Kenny, Bertrand Lemennicier, Marjorie McElroy, Steve Medema, and Howard Yourow. 
This Chicago-style approach, sometimes known as "Price Theory" because of the fundamental role that prices often play, is exemplified in the path-breaking work of Gary Becker, Ronald Coase, Milton Friedman, Sherwin Rosen, George Stigler, and many others. Price theory has shed light not only on the most fundamental topics of traditional economics (e.g. consumption, saving, taxation, regulation), but also pioneered the use of economic tools in studying a wide range of other human behavior (e.g. crime and corruption, discrimination, marriage). [italics added]

Mission statement prior to the inaugural conference at the Gary S. Becker Center on Chicago Price Theory, April 2006.

\section{Introduction}

Gary Becker is heir to the Chicago tradition in price theory developed by Frank Knight and Jacob Viner and, later, by Milton Friedman and George Stigler. Some view Gary Becker, who was a student of both Viner and Friedman, as a torchbearer of the Chicago approach to price theory. For instance, Van Overtveldt, who defines the Chicago School in terms of "a belief that the price mechanism is the key element in successfully solving economic problems" (Van Overtveldt 2007, p. 76), finds this Chicago approach "carried to its highest point by Milton Friedman and Gary Becker" (ibid.). Others have distinguished between two second-generation Chicago traditions in price theory: Friedman's and Stigler's. For instance, Medema (2008) distinguishes between the Knight-Viner tradition in Chicago price theory pursued by Friedman and the Stigler-Becker tradition. Friedman's price theory was Marshallian in its emphasis on partial equilibrium market analysis (Medema 2008, Van Overtveldt 2007) and the price mechanism. Stigler and Becker have emphasized rational choice and economics as the "science which studies human behaviour as a relationship between ends and scarce means which have alternative uses," in the tradition of Robbins (1962, p.16).

As recognized by the Nobel Prize committee and others-including Fuchs (1994) and Lazear (2000)--Becker has played a central role in the expansion of economics that has also been associated with Chicago. Becker's seminal work on marriage is a primary example of his role in this expansion. At the micro-level of decision-making, Becker's theory of marriage uses rational choice theory, and in that sense his economic analyses of marriage can be placed in a category parallel to the economic analyses of law that Becker, Stigler, and Posner pioneered at Chicago. The economics of marriage also entails a macro-level of analysis. Here Becker uses two types of model: Marshallian partial equilibrium models central to the tradition of Chicago Price Theory emphasized by Friedman, and optimal sorting models that are less typical of that tradition.

Scholars studying the Chicago tradition in economics, and the place of Becker in that tradition, will find it informative to examine Becker's theory of marriage. Such examination starts with the recognition that Becker's theory of marriage contains many models, including some that are associated with Chicago Price Theory as taught by Friedman and based on Marshall's partial equilibrium analyses. Other elements in Becker's theory of marriage are linked to other modeling traditions, including optimal assignment theory.

The next section presents the basic principles of Price Theory at the University of Chicago as taught by Friedman in the 1970s, around the time that Becker arrived there as a 
full professor in 1969 and wrote his theory of marriage. Section III presents Becker's theory of marriage, based mostly on his first article on marriage that appeared in 1973 and on the chapters on marriage from his Treatise on the Family first published in 1981. Section IV examines some of the possible intellectual influences on Becker's theory of marriage. Section $\mathrm{V}$ compares Becker's research on marriage with that of some scholars interested in intramarriage distribution. It also documents that Becker's students at Chicago were more interested in Becker's Friedmanian models of marriage than in his optimal assignment models.

\section{Chicago Price Theory: The Friedman Tradition}

In his chapter on Milton Friedman, published in a volume about famous Chicago professors (Shils 1991), Becker (1991b, p. 140) describes Milton Friedman as "the dominant member of the so-called Chicago school of economics" during his tenure at Chicago. "The economics department increasingly reflected his approach and interests. These included deep commitment to the truth, appreciation of markets and free enterprise, frank and blunt discussion, and enormous zeal to convince the heathen. But most important was the commitment to economic analysis as a powerful instrument for interpreting economic and social life." (Becker 1991b, p. 146).

This dominance originated significantly from Friedman's influence as teacher of one section of a two-quarter sequence on price theory taken by all graduate students in economics (Becker 1991b, Medema 2007, p. viii). What Friedman taught in his course therefore gives a good sense of what Chicago price theory stands for. According to Becker Friedman's price theory course emphasized "so-called partial equilibrium supply and demand analysis." Not unique to Chicago, this method of analysis was also used by many of Friedman's predecessors, including Alfred Marshall. Medema identifies the "Marshallian emphasis" in Friedman's approach to price theory and notes that "Marshall's Principles of Economics was the main text for Friedman's course until replacement" by his own textbook (Medema (2007, p. ix).

In his classes Friedman (1976, p. 8) contrasted the price mechanism behind supply and demand analysis with a command mechanism: "there are fundamentally only two principles that can be used to allocate resources, organize production, and distribute the product: centralized authority (command) and the market (voluntary exchange)." ${ }^{2} \mathrm{He}$ promoted the price system as an organizing mechanism and was critical of collectivist countries emphasizing command, while recognizing that most countries mix the two principles: "the great difficulty with the attempts of collectivistic countries to rely more heavily on market mechanisms arises from their trying to separate the distribution of the product from the use of prices to transmit information and organize production." (Friedman 1976 , pp. 8-9). Friedman also taught that we tend to underestimate the accomplishments of the price system, "for we are hardly conscious of its workings." (Friedman 1976, p. 10).

"One artifact of Friedman's Marshallian bent was that he paid scant attention to general equilibrium theory.” (Medema 2007, p. ix). According to Becker (1991b, p. 143), writing about Friedman's class: "the impression was conveyed that most mathematical economics was sterile, and that models of general equilibrium tend to be untestable." Becker has distanced himself from Friedman in this regard: "I now believe that he [Friedman] was excessively negative on the prospects for developments in these areas."

\footnotetext{
2 Friedman (1976) and earlier editions is based on students' class notes.
} 
Another principle that Friedman stood for is that he opposed labeling courses as either 'micro-economics' or 'macro-economics.' He saw every economic problem as involving both an individual and a market (aggregate) level. Accordingly, every so-called macro problem has its micro foundations, and every micro decision has macro implications.

Finally, Friedman demonstrated how price theory applied to a wide variety of problems. The expansion of economics accomplished by Becker received Friedman's full endorsement.

This paper examines Becker's theory of marriage in light of Chicago price theory as taught by Friedman.

\section{Becker's Models of Marriage}

The economics of marriage occupies a prominent place in Becker's work and features among the major contributions recognized by the committee that awarded him the Nobel Prize in 1992. Becker has emphasized the economics of marriage in the context of his research on the family. The first article on the family that he published in a major journal is "A Theory of Marriage Part I" that appeared in the Chicago-based Journal of Political Economy (JPE) in 1973. It was soon followed by another JPE article (Becker 1974). ${ }^{3}$ His influential Treatise on the Family (Becker 1981, 1991a) covers the subject of marriage before it delves into other topics such as fertility and investments in children. ${ }^{4}$ Other than a brief note published by Martin Bronfenbrenner in 1971 and unpublished papers by students at Columbia-Reuben Gronau (1970) and Fredericka Pickford-Santos (1970)--Becker's 1973 article is the first economics article on marriage.

In view of the importance of the price mechanism in Chicago Price Theory when Becker completed his first article on marriage, one expects that prices play a major role in Becker's theory of marriage. They indeed do, but only in some of Becker's models of marriage. In contrast to economic theories built around one major model, Becker's theory of marriage includes a number of models. Becker recognizes that he takes various approaches to analyze marriage at the beginning of the Treatise's first major chapter about marriage markets, the chapter on polygamy:

"An efficient marriage market develops "shadow" prices to guide participants to marriages that will maximize their expected well-being. These prices, central to the analysis in this chapter and the subsequent one, are responsible for the more powerful implications found in these chapters than in traditional discussions of marriage. Some other approaches are evaluated in Chapter 4 [on assortative mating]." Becker (1981, p. 39, italics added).

The same theoretical approaches are also found in the earlier JPE articles. This discussion principally follows the order in Becker (1973). Some relevant differences between

\footnotetext{
${ }^{3}$ Becker's earlier economic analysis of fertility (Becker 1960) appeared in a conference volume published by Princeton University Press and NBER.

${ }^{4}$ The second edition of the Treatise, published in 1991, is identical to the first except for a new introduction. Becker's Treatise on the Family (Becker 1981, 1991a) is Becker's most cited item. According to Google Scholar, on August 22, 2008 the two editions of the Treatise on the Family had been cited 5554 times. In comparison, Becker's second most cited item, his book Human Capital (Becker 1964), had been cited 4230 times. The Treatise (1981) also offers an analysis of altruism in the family (Chapter 8), of analogies between mating among humans and among other species (Chapter 9), of divorce (Chapter 10), and some explanations for changes in family characteristics in a number of industrialized countries in the period between 1950 and 1978 (Chapter 11).
} 
the analyses in the article and the book are pointed out below. I also refer to Becker's latest publication on marriage: a chapter on marriage included in Social Economics (Becker and Murphy 2000).

All of Becker's analyses of marriage are grounded in the New Home Economics in that he analyzes households as firms involved in production. Covering some of the same ground as earlier work by Margaret Reid (1934), the New Home Economics was developed by Becker and Jacob Mincer while both were at Columbia in the 1960s. ${ }^{5}$

Another common thread running through all of Becker's analyses of marriage is that individuals are assumed to be rational or utility maximizing. This fits well with Becker's role as a proponent of rational choice and his broad research agenda involving applications of his theoretical approach "to all human behavior, be it behavior involving money prices or imputed shadow prices" (Becker 1976a, p. 8). It is one of the three assumptions he emphasizes in the following famous statement from the introduction to his Economic Approach to Human Behavior (Becker 1976a), a collection of articles including his JPE articles on marriage as well as applications of economics to fertility, crime and politics:

The combined assumptions of maximizing behavior, market equilibrium, and stable preferences, used relentlessly and unflinchingly, form the heart of the economic approach as I see it (Becker 1976a, p. 5).

The assumption of 'maximization' is clearly understood. But what is meant by "market equilibrium". It is a 'macro' concept in the sense that it involves aggregation, but is it partial or general equilibrium? Is it obtained as a result of a clearing process based on prices or is it the result of an optimal assignment by non-market agencies such as a central planning agency? Becker's analyses of marriage in Becker (1973), as well as in the Treatise, refer repetitively to the concepts of 'market' and 'market equilibrium'. To understand what they mean it helps to start with a caveat appearing at the beginning of Becker's systematic analysis of marriage in the Treatise (Becker 1981, 1991a), but not in Becker (1973):

“The phrase 'marriage market' is used metaphorically and signifies that the mating of human populations is highly systematic and structured.” (Becker 1981, p. 39).

While Becker's theory of marriage is Friedmanian in its avoidance of the terms 'micro' and 'macro' it can nevertheless be said to include both micro and macro levels of analysis. The following discussion emphasizes the macro level of analysis that includes models of marriage market equilibria.

Becker's theory of marriage starts with micro foundations including discussions of household production and individual gains from marriage. In the language of Becker (1973), two persons, $\mathrm{M}$ and $\mathrm{F}$, are the decision-makers who compare the product they can produce alone with the income they will get if they marry each other. ${ }^{6}$ The total income after marriage is the sum of their individual incomes and corresponds to the marital output. For two individuals to want to marry that marital output needs to be at least as large as the sum of their single outputs. The difference between the marital output and the sum of the single outputs of two individuals is defined as their gain from marriage. This framework is used to

\footnotetext{
${ }^{5}$ See Grossbard-Shechtman (2001) for more on the history of the New Home Economics at Columbia.

${ }^{6}$ One can infer that $\mathrm{M}$ is a male and $\mathrm{F}$ a female, but this is never explicitly stated in Becker (1973). In contrast, in Becker (1981) decision-makers are explicitly identified as male and female.
} 
analyze two major individual (micro) decisions: "to marry or not" and "if marriage, whom to marry," decisions related to production and allocation. Becker then proceeds with how variables such as individual wage rates in the labor force and productivity of time in household production may affect the gain from marriage and the probability of marriage. A third micro-level question asked by Becker deals with a distribution issue: "what explains the division of marital output?"

Becker's theory of marriage addresses two major 'macro' questions: (1) what explains polygamy rates, and (2) in the aggregate do male and female individual traits sort positively or negatively? While the main macro questions addressed in the JPE articles and the Treatise are the same, there are many differences between the two publications.

Macro analysis in Becker (1973). Becker (1973) briefly mentions polygamy in section 2 on the gain from marriage and then presents section 3 entitled 'the marriage market and sorting of mates'. That is subdivided into part (a) on optimal sorting and part (b) on assortive mating. The analysis in that last sub-section leads to testable predictions regarding negative sorting according to wage and positive sorting according to most other individual characteristics. A more analytical discussion of polygamy is found in section 4 entitled 'the division of output between mates'.

The first mathematical macro model in Becker (1973, Section 3a) is an optimal sorting model similar to some of the optimal assignment models in Koopmans and Beckmann (1957). Becker (1973) explicitly recognizes the similarity with the KoopmansBeckmann models of optimal assignment: "the theory of optimal assignments, which has the same mathematical structure as the sorting of persons by marriage, implies the existence of a set of incomes..." (Becker 1973, p. 824). Koopmans and Beckmann (1957) is cited in footnote 24. Koopmans and Beckmann studied sortings between factories and land for building the factories and were particularly interested in the question "whether a price system is possible which will sustain an optimal assignment if locational decisions are made independently by $n$ entrepreneurs..." (Koopmans and Beckmann 1957, p. 56). They offered "insight into the possibilities and limitations of price systems as means of decentralizing the allocation of indivisible resources." (Koopmans and Beckmann 1957, p. 71). This question is also of interest to Becker (1973).

As is common in the literature on optimal assignments, Becker uses game-theoretical language when defining the optimal sorting as the core: "no coalition outside the core could make any of its members better off without making some worse off" (Becker 1973, p. 824). Of the optimal sorting model of mates Becker writes: "the marriage market chooses not the maximum household commodity output of any single marriage but the maximum sum of the outputs over all marriages, just as competitive product markets maximize the sum of the outputs over all firms." (Becker 1973, p. 824, italics added). The 'marriage market that chooses' appears to imply a general equilibrium, not a partial equilibrium a la Marshall.

It is implicit from Becker (1973, Section 2a) that a price mechanism facilitates the sorting of mates. "Each marriage can be considered a two-person firm with either member being the 'entrepreneur' who 'hires' the other at the salary $m_{i j}$ or $f_{i j}$ and receives residual 'profits' (...). Another interpretation of the optimal sorting is that only it enables each 'entrepreneur' to maximize 'profits' for given 'salaries' of mates... With all other sortings, some 'entrepreneurs' could do better by 'hiring' different mates than those assigned to them." (Becker 1973, p. 825, where $m_{i j}$ and $f_{i j}$ are individual incomes of married mates). However, reference to prices and profits is found in only one paragraph and is not central to 
the analysis in this section. ${ }^{7}$ The prices in this analysis are the shares of marital output obtained by individual spouses.

This analysis of sorting depends on certain assumptions. One set of assumptions is that men can be ranked in terms of their potential productivity in marriage, that the same holds for women, and that a matrix can be constructed indicating the maximum household output each potential match can produce.

A second assumption is that marital output can be divided between mates. "Some of the output may not be divisible at all and may constitute a public or family commodity.... or some divisions may not be feasible because they are not enforceable." (Becker 1973, pp. 8345). Becker examines how his conclusions regarding positive or negative sorting depend on whether the division of marital output is divisible and variable, or indivisible and fixed. Indivisibility implies that the earlier paragraph on men and women hiring each other as husbands and wives is of limited applicability.

The next section in Becker (1973), Section 4, assumes complete divisibility and negotiability of marital output and presents a demand and supply analysis with one type of man and one type of woman. Here markets are like the markets in Friedman's price theory course. Prices serve as a mechanism for reaching allocative equilibrium and Demand and Supply curves are drawn. The ensuing market equilibrium implies both a marriage rate (on the quantity axis; the rate equals $100 \%$ if the number of men and women is equal) and a division of marital output (the price axis). Becker's comparative statics analysis includes predictions regarding the effect of sex ratio on marriage rates and division of marital output. This model's implications for distribution of output or income between mates are emphasized by the section's title: 'the division of output between mates'.

In Becker (1973, Figure 2) one also finds a second Marshallian market equilibrium model with multiple types of men and women participating in separate but inter-related marriage markets. Each market is composed of homogeneous women and homogeneous men. In more modern terminology, this model can be labeled as a "hedonic" market model. Each market establishes an equilibrium price and quantity that depend on the number of participating men and women and on substitutability between various types of potential spouses.

The models most compatible with Friedman's price theory are the Marshallian partial equilibrium models with supply and demand. In Becker (1973) they are placed after optimal sorting models addressing the macro question of most interest to industrialized societies: who matches with whom. Demand and supply analysis is primarily applied to explain polygamy, but is also used to explain division of marital income. One paragraph discusses empirical applications to intra-household allocation.

The JPE articles of 1973 and 1974 were the basis for the chapters on marriage in the Treatise, first published in 1981.

Macro analysis in Becker (1981). In the Treatise on the Family the chapters dealing exclusively with marriage address the same principal macro questions: polygamy and assortative mating. However, from 1973 to 1981 the order of presentation was reversed. The first of these chapters starts with supply and demand models assuming divisibility and

\footnotetext{
${ }^{7}$ I was first exposed to Becker (1973) while taking Becker's price theory course in the winter of 1973. Reading about husbands and wives paying each other salaries in Becker (1973) made it easy for me to see parallels between labor markets and marriage markets.

${ }^{8}$ Rao (1993) is possibly the first to use the term 'hedonic' in the context of marriage markets. Hedonic markets were first introduced by Sherwin Rosen (1974), in a different context.
} 
negotiability. However, such Marshallian models are short-shrifted in Becker (1981) in two regards. First, Marshallian models are solely presented in the context of a chapter on polygamy, a topic of limited interest to most economists of the household. In contrast, in Becker (1973) these models appeared in a section on intra-household distribution, a topic of considerable importance in industrialized societies and elsewhere. Second, the most relevant hedonic model, with many types of men and women, is dropped. ${ }^{9}$ Instead, the Treatise adds another version of the simple demand and supply model assuming only one type of women and one type of men, and another simple model with only two types of men and one type of woman.

In both Becker (1973) and the Treatise Becker refers to Koopmans and Beckmann's optimal assignment models, but only the Treatise includes a reference to Gale and Shapley's (1962) assignment model. Becker (1981, p. 85) contrasts his optimal assignment model with theirs. His model assumes that different people use the same ranking and results in the division of marital output being determined by the marriage market, possibly with the help of a price mechanism. ${ }^{10}$ Gale and Shapley assumed that each person has "a given ranking [among] potential mates that determines rather than is determined by the equilibrium sorting." (Becker 1981, p. 85). They only required that optimal assignments be stable and allowed for different persons using different rankings. Optimal sorting models based on Gale and Shapley have been used by central planners allocating medical residents among competing hospitals. ${ }^{11}$ However, Becker's optimal assignment problem can also be solved with the help of a command mechanism. According to Becker (1981, p. 85), "permitting the marriage market to determine the division of output [among mates] and imposing that division by Equation 4.20 frequently give the same sorting."

Readers who wonder what kind of price mechanism operates in Becker's optimal sorting model get less help from Becker in 1981 than in 1973, for the descriptive paragraph about marriage 'entrepreneurs' 'hiring' different potential mates at certain 'salaries' that was found in Becker (1973) is omitted from the Treatise. It is also omitted in Becker and Murphy (2000). One finds sentences such as "The bumping of lower-quality men out of their marriages through competitive reductions in the incomes of higher-quality men continues until the incomes of the lowest-quality men are reduced to their single levels." (Becker 1981, p. 79) However, Becker does not emphasize that these incomes are shares of marital incomes and serve as prices.

In 1973, Demand and Supply models were the main models that Becker used to explain variation in individual shares of marital income, and this was emphasized in the subsection's title. Becker specifically mentioned how such models can help explain individual consumption of goods and leisure by married partners (Becker 1973 in 1976, p 838). In 1981, a similar paragraph on the division of marital output and its implications for individual consumption and leisure is found in the chapter on polygamy (Becker 1981, p. 42).

\footnotetext{
${ }^{9}$ When asked why he omitted that model from the Treatise, Becker answered: "My Treatise was considered by me to be a complement to my previous work, not a substitute. So I did not go over everything in the earlier papers that I considered to be valid and sometimes even important." (Becker, 2004) In that same email exchange, Becker stated that he had not changed his mind about the validity and applicability of demand and supply models to the study of marriage: "I never abandoned my view that imputations to men and women are determined by a competitive marriage market - what you call the 'supply demand' framework."

10 As shown e.g. by Werner Hildenbrand (1982), some sorting models converge towards competitive equilibria. I owe this point to William A. Brock.

${ }^{11}$ I owe this point to Valerio Filoso.
} 
Relative to the JPE articles, Becker's Treatise and Becker and Murphy (2000) add more discussion of the assumptions of either rigidity or flexibility in marriage-related prices such as marital incomes. For example, Becker (1981, pp. 85-6) discusses the following reasons why the division of marital output may be inflexible and marital incomes may not follow fluctuations in market conditions: household goods may be household public goods, there may be shirking in the family, and "men have sometimes been given legal control over the assignment of shares [of marital output]." Becker (p. 87) also hypothesizes that men may be more likely to silence the market mechanism when women's "equilibrium income is a larger share of marital output (a larger share may not be as readily appropriated by wives)." In other words, if women's equilibrium income/price in marriage markets is higher, men are more likely to use force to control women and take away part of the incomes that women would get if marriage markets cleared, i.e. women may get the equivalent of 'controlled rents'. Given divergences between actual individual marital income and equilibrium income, "bride prices and dowries raise or lower marital incomes to the levels mandated by the equilibrium sorting. My assumption that marital incomes are flexible appears highly reasonable, therefore, when the purpose of bride prices and other capital transfers contingent on marriage is understood" (Becker 1981, p. 87, italics in the original). In the Treatise bride prices and dowries play a relatively more important role in the description of a market mechanism. ${ }^{12}$ The fact that such transfers are rare in the U.S. and other Western countries may have limited the appeal of Becker's model with flexible prices to most readers.

Becker's economic theories of marriage carry implications for research on problems of allocation, production, and distribution. For instance, in his Demand and Supply analysis, equilibrium conditions entail both an equilibrium quantity (associated, for example, with a given marriage rate or polygamy rate) and an equilibrium price. The price dimension can be an explicit price, such as dowry, or an implicit price, such as the level of marital income going to men or women. Some studies are more interested in quantity dimensions such as marriage rates; others are more interested in questions of intra-household distribution such as 'how much of the marital output is going to wives and not husbands?' Marriage-related prices affect such distribution. Marital sorting by spouses' characteristics captures a nonmonetary dimension of market equilibrium.

Becker's theory of marriage consists of a number of different models. The more applicable the assumptions underlying partial market equilibrium analysis, the more the model fits within Chicago Price Theory as taught by Friedman. Optimal sorting models are less Friedmanian than Demand and Supply models of marriage, for the markets associated with optimal sorting of mates could clear as a result of either a decentralized price mechanism or the actions of a central planner.

\section{On the Context of Becker's Marriage Models}

The particular mix of Demand and Supply models and optimal sorting models that Becker used in his theory of marriage needs to be considered in the context of what Becker learned from his mentors, in particular Friedman, Viner, Schultz, and Gregg Lewis. He has acknowledged their influence, but not specifically their influence on his theory of marriage. It is also interesting to examine who of Becker's colleagues at Chicago are acknowledged in the JPE articles on marriage and the Treatise. The context examined here includes research on marriage by sociologists and the popularity of game theory in the 1970s.

12 Becker (1973, p. 836), mentions bride prices and dowries, but gives them even less space than Becker (1981). 
Chicago Mentors. When Becker returned to Chicago in 1969 three of the professors he had been closest to in the 1950s, when he was a graduate student and assistant professor, were still active in the department of economics: Friedman, H. Gregg Lewis, and T.W. Schultz. Becker respected them and they had stood behind him when he wrote on the economics of discrimination in the 1950s (Becker 1992). Friedman, Gregg Lewis and Schultz supported Becker as he developed his ideas on economics of marriage in the early seventies, in part by attending Becker's workshop in applications of economics (Friedman occasionally so, Schultz and Gregg Lewis regularly).

Becker has called Friedman his most influential mentor (see Becker 2006). Friedman and Becker continued to have a close friendship after Friedman left Chicago for the Hoover Institute in 1976, and Friedman made valuable comments on Becker's Treatise. That partial equilibrium models central to Friedman's version of Chicago Price Theory play an important role in Becker's theory of marriage is an indication of the strength of the Friedmanian influence on Becker's approach to economics.

Gregg Lewis, whose seminar in research in labor economics he had attended while in graduate school, had been Becker's principal advisor on his dissertation. Gregg Lewis has been called the father of Modern Labor Economics by Mincer (2006) and the founder of the Chicago School of Labor Economics by Becker (1976b). Becker's close relationship with Gregg Lewis is recognized in Melvin Reder (1982, p.33). Gregg Lewis contributed part of the technical appendix to Becker's 1973 theory of marriage and read all of Becker's early work on marriage very carefully, integrating ideas from these articles in his own courses in labor economics. ${ }^{13}$ He did not leave for Duke University until 1975.

As chair of the department, Schultz had been influential in the 1950s (see Emmett 2007). His work on human capital inspired both Becker and Mincer (who arrived as a postdoc at Chicago in 1957). Even though Schultz retired in the early 1970s, he was still very active in the department throughout the seventies and gave financial support to some of the students in Becker's workshop, including this writer. He also edited a volume on economics of the family published by the National Bureau of Economic Research (NBER) and the University of Chicago Press (Schultz 1974) and made helpful and detailed suggestions on all the chapters in Becker's Treatise.

The presence of these mentors at Chicago while Becker wrote his theory of marriage helps account for the central place of Demand and Supply models in his theory.

Other Chicago Economists. Becker $(1973,1981)$ mentions that his optimal sorting model is similar to some of the optimal assignment models in Koopmans and Beckmann (1957). Tjalling Koopmans was on the Cowles Commission for Research in Economics at Chicago from 1944 to 1955, which includes Becker's student years at Chicago. The year that Becker arrived for his doctorate, 1951, is also the year that Martin Beckmann arrived to work for the Cowles Commission. Becker's main mentor, Milton Friedman, and others Becker was close to, had little to do with that Commission (see Van Overtveldt 2007). Nevertheless, it is likely that Becker had some interactions with Koopmans or Beckmann and learned about optimal assignment models during that period.

From the acknowledgements and notes to the JPE articles and the Treatise one gains some further insights as to the network of economists with whom Becker discussed his theory of marriage. During much of the period that Becker wrote articles and chapter books

\footnotetext{
13 Two quarterly courses in labor economics that Gregg Lewis taught in 1974 included extensive references to Becker's theories on the family. Becker and Gregg Lewis (1973) also co-authored a theoretical paper on the trade-off between child quality and number of children.
} 
on marriage-more specifically, starting with 1972, William A. Brock, a Ph.D. in mathematics from UC Berkeley, was a member of Chicago's economics department (he left in 1981). Becker thanks Brock for his help with some of the mathematical appendices to his theory of marriage. That Brock had been hired at Chicago and offered a tenured position reflects the economics' profession increased interest in mathematical modeling in the 1970s. This trend and Brock's presence may have been factors facilitating Becker's research on optimal sorting.

Besides Schultz, colleagues of Becker at Chicago who are acknowledged in the Treatise for helpful and detailed comments on the whole manuscript are Robert Michael, Richard Posner, Sherwin Rosen, and George Stigler. Furthermore, Rosen's (1981) model of superstars had a significant impact on the chapter on polygamy. Rosen had also been trained at Chicago and arrived in Chicago in 1977 from Rochester. He became Becker's partner in running the workshop in applications to economics.

In the Treatise, Becker also acknowledges comments from James J. Heckman, who arrived as an assistant professor in 1973 and participated in Becker's workshop for a number of years, and from Robert Lucas, who joined the department in 1974.

Research in Sociology. It is even true today, and it was certainly the case in the 1970s: research on marriage and the family is more likely to be produced by sociologists than by economists. To understand Becker's theory of marriage as it appeared in the JPE articles and the Treatise, it helps to know that Becker wanted his work on marriage and the family to reach sociologists (see the preface to the Treatise). In part, Becker called his book a Treatise because he wanted to avoid a title containing the word 'economic'. ${ }^{14}$ In the late 1970s, when Becker was working on the Treatise and his work was being published exclusively in economics venues, sociologists had not yet taken an interest in Becker's ideas about the family. When the Treatise was being prepared there was some antagonism to economists' entry into a domain traditionally allocated to sociologists (see, for instance, Remi Clignet and Joyce Sween 1977). At that time even his sociology colleagues at Chicago who researched the family paid little attention to Becker's theories on the topic. Given that the family has traditionally been a topic studied by sociologists, Becker wanted the Treatise to make his theory of marriage more appealing to sociologists. This motivation to reach out to sociologists may also have led Becker to avoid statements, assumptions, and jargon likely to alienate readers not trained in economics. ${ }^{15}$ In this light it is easier to understand the prominence of sorting questions in Becker's writings on marriage. Sorting, associative mating and the related concepts of hypogamy and hypergamy are all important in the sociology of marriage.

Game Theory. Becker had been exposed to game theory models as an undergraduate at Princeton, before they gained in popularity in the 1970s and 1980s (see Becker 2007). When game theory models of marriage were just starting, in the mid 1970s, Becker invited Louis Wilde, a student at the University of Rochester, to come to Chicago and participate in his

\footnotetext{
14 This is based on conversations with Becker in the years 1974-1976. He did not call it a 'treatise' to imply that it replaced earlier articles, as was perceived by Sarah Hamersma, a recent Ph.D in economics from Wisconsin.

15 Becker's efforts at reaching out to sociologists of marriage were hugely successful: Becker has achieved undeniable prominence among quantitative sociologists and demographers studying marriage. That the study of marriage is primarily a field dominated by sociologists helps explain Becker's prominence in quantitative research on marriage, whether generated by sociologists or economists. Few articles on marriage by sociologists or demographers are currently published without a reference to Becker. One of the reasons that Becker is among the most cited economists in the world is that his citations also come from social scientists outside economics (not only those who write on marriage), and sociologists tend to cite more than economists.
} 
workshop. A few years later, in the period 1979-1981, one of the principal architects of this bargaining approach, Marjorie McElroy, was invited for a post-doc at Chicago. During that time she presented her not-yet-published bargaining analysis of marriage (co-authored with her student Mary Jean Horney and published in 1981) in Becker's workshop in applications of economics. According to McElroy, her "experience at Chicago changed [her] whole career..." (McElroy 2006). However, he has not used bargaining models in his theory of marriage. Becker seems to have influenced bargaining modeling of marriage more than viceversa.

\section{Becker's Models and Other Economic Analyses of Marriage}

This section examines two developments in the economics of marriage in the period 1970-1995: studies of intra-household allocation and research on marriage by Chicago economists other than Becker.

Intra-household Distribution. Intra-household distribution is an important topic of interest to scholars who entered the field of economics of marriage after 1980. Preferred models among these scholars have included the bargaining models of Marjorie McElroy and Mary Jane Horney's (1981), in which two agents decide on distribution and production according to some kind of bilateral monopoly game, as well as two-person models of marriage by Marilyn Manser and Murray Brown (1980), Patricia Apps and Ray Rees (1988), Francois Bourguignon and Pierre-Andre Chiappori (1992), and Shelly Lundberg and Robert Pollak (1993). The great interest of economists, especially development economists, in intrahousehold distribution problems has contributed to the growth in popularity of two-person models of marriage (see, for instance, Angus Deaton, Javier Ruiz-Castillo and Duncan Thomas 1989; John Hoddinott and Lawrence Haddad 1995). None of these scholars obtained their doctorates at the University of Chicago.

Becker's modeling of intra-household distribution-in particular, his Demand and Supply analyses of individual marital incomes--preceded most of the economic research in this area, but it is rarely cited in studies of intra-household allocation or distribution. ${ }^{16}$ Instead, these studies have often criticized Becker's (1965) earlier household maximization models that don't recognize divergent interests on the part of each individual member of a couple. The implications of Becker's Demand and Supply models for intra-marriage distribution of income were also overlooked in Robert Pollak's (2003) recent survey of Becker's economics of the family.

Research on Marriage by Chicago Economists Other than Becker. Becker is not the only economist associated with Chicago who wrote on the economics of marriage during the period 1970-1995. An early publication in the JPE, the economics journal edited by faculty at Chicago, addressed the topic, and so did research by younger scholars who participated in Becker's workshop at Chicago. ${ }^{17}$

The first article that the JPE published on marriage is a brief note by Martin Bronfenbrenner (1971), who had obtained his Ph.D at Chicago in 1939 and was by then a well-known scholar specialized in so-called 'macro-economics'. This note consists of a Marshallian analysis of Indian marriage markets using explicit bride prices and dowries.

The Chicago economists working on the economics of marriage in the 1970s were all associated with Becker. One expects that with Friedman's influence still pervasive at

\footnotetext{
${ }^{16}$ When I called Becker's attention to this apparent oversight of the bargaining theorists of marriage, in January 1993, he agreed with me (Becker 1993).

17 More on the workshop system at Chicago can be found in Emmett (2007).
} 
Chicago, Becker's models of marriage with an explicit price mechanism--models closer to Friedman's Price Theory--would have had more appeal to these Chicagoans than optimal sorting models. It is indeed the case that Becker's optimal sorting models found few followers among the younger researchers active in the field of economics of marriage and participating in Becker's workshop at Chicago in the 1970s. Instead, these researchers turned to Marshallian models of marriage. This holds for Lisa Landes, who had studied at Columbia, and three students at Chicago whose dissertations were supervised by Becker: Alan Freiden, Amyra Grossbard, and Michael Keeley. The empirical models that they estimated (Freiden (1972, 1974), Keeley (1974, 1977), and Grossbard (1976, 1978b)) addressed questions phrased in the language of Demand and Supply and inspired by Becker's Friedmanian models. Landes, who in the 1970s worked with Becker on an analysis of divorce at Chicago (the third author being another of Becker's former students at Columbia, Robert T. Michael, see Becker, Landes and Michael 1977), published a pioneering piece on a marriage-related price: alimony. It was published in a Chicago journal, the Journal of Legal Studies (Landes 1978), right around the time Becker was writing the Treatise. ${ }^{18}$

Keeley and Grossbard also made theoretical contributions based on Becker's Marshallian models of marriage. Keeley $(1974,1977)$ developed a search theory based on the concept of 'marital wage' defined as the equilibrium value of a spouse in his or her marriage market. His search model of marriage (Keeley 1977) appeared around the same time as Becker's (Becker, Landes, and Michael 1977). Both articles derive predictions from search theory, such as the prediction that individuals with rare characteristics may be less attractive relative to people with more generally desired characteristics. The exposition by Keeley relied on an explicit price mechanism - the concept of marital wage. This allowed him to draw direct parallels with the search literature in labor markets. The search model in Becker et al. was not as explicit in its reference to a price mechanism.

Grossbard addressed the question "how do you value the price of time?" with the help of a Demand and Supply model of marriage. The question of value of time had also been addressed in Becker (1973) when he proposed a comparison between shadow prices of mates' time and their wages in the labor force (Becker 1973, p. 818). This is a place where Becker could have applied the concept of salary, a function of marriage market conditions (see Becker 1973, p. 824). However, in Becker (1973) these "salaries" don't indicate opportunity costs of time and therefore don't drive decisions related to allocation of time. In contrast, the 'wife-wages' introduced by Grossbard (1976), while reminiscent of Becker's 'salaries' and Keeley's 'marital wages', have served as the basis for estimating the opportunity cost of time (Heer and Grossbard-Shechtman 1981, Grossbard-Shechtman 1984). ${ }^{19}$

Some participants in Becker's workshop at Chicago in the 1980s were also inspired by Becker's models of marriage. Elizabeth Peters (1986), who studied at Chicago in the 1980s after the Treatise's publication, used Chicago Price Theory and game theory in her dissertation. Bertrand Lemennicier visited Chicago during this period. He had presented a paper to Becker's workshop on applications of economics in 1977 on the topic of division of labor within the family and its impact on gains of marriage and potential divorces (later published as Lemennicier 1980). Lemennicier ((1988, Chapter 4 Le Prix de la Femme dans nos

\footnotetext{
18 Unlike the other studies mentioned here, her study was not cited in the Treatise.

${ }^{19}$ Grossbard later switched from the term 'wife-wage' to a gender-neutral 'quasi-wage' and applied the concept to analyses of labor force participation (e.g. Grossbard-Shechtman 1984, 1993 and Grossbard and AmuedoDorantes 2007).
} 
Societes Contemporaines [the Price of Women in our Contemporary Societies]) contains an analysis of alimony compatible with Marshallian analysis.

The most explicit marriage-related prices, dowries and bride prices, have received attention from Chicago economists other than Bronfenbrenner and Becker, namely (in chronological order) Grossbard (1978a), Papps (1983), and Botticini and Siow (2003). ${ }^{20}$

Implications. Applications of the economics of marriage that became popular in the 1980s and 1990s outside Chicago dealt with non-price dimensions of intra-household distribution. To the extent that Chicagoans were interested in distribution between husbands and wives, they examined prices such as bride price and alimony. Following Becker's own emphasis, the research by scholars trained at the University of Chicago in the 1970s and 1980s focused principally on the quantity dimension of marriage, with behaviors such as marriage rates, divorce, and polygamy.

Questions regarding marriage can be addressed with a number of alternative models, including Becker's various models and two-person models such as bargaining models. Scholars studying intra-household distribution have tended to use bargaining models and to cite Becker's economic theory of marriage less than is the case with Chicago-trained scholars addressing mostly other questions.

Clearly the students of Becker were more influenced by the questions he asked and the models he used than economists trained elsewhere. Chicago students who entered the field before the Treatise's publication and for a short time thereafter had the opportunity to take a course with Becker on the economics of the family. It is noteworthy that Becker's models that most inspired Chicago-trained scholars of marriage in the 1970s are the most Friedmanian parts of Becker's theory: the Marshallian Demand and Supply models using a price mechanism. These models are more compatible with the training that students received at Chicago at that time, when Friedman was teaching them a course very similar to the course that Becker had taken himself, twenty years earlier. By the time Peters entered the field at Chicago in the 1980s, Friedman was not teaching any more. Game theory had become more popular everywhere, including at the University of Chicago, and her work includes a game-theoretic analysis.

The heavy influence of Becker's models on Chicago economists stands in contrast to the minimal impact his ideas on intra-marriage distribution seem to have had on research by scholars writing on that topic outside Chicago. This could be related to the way that Becker presented his ideas. Scholars may have missed Becker's explicit reference to intra-household allocation contained mostly in one paragraph in either Becker (1973) or Becker (1981). If they entered the field after 1981, and became acquainted with Becker's theory of marriage mostly via the Treatise first published in 1981, they many not have read the original JPE articles and may have not seen the section in Becker (1973) entitled 'the division of output between mates.'

\section{Conclusions}

This paper started with a statement describing the mission of the Gary S. Becker Center on Chicago Price Theory, and the use of that theory in studies of marriage. This paper has documented that Becker's theoretical modeling of marriage included two very different types of model: optimal sorting models and demand and supply models. One wonders whether the optimal assignment models of marriage in Gary Becker's theory of marriage have a place in the Gary Becker Center on Chicago Price Theory. Becker's

20 Papps and Siow obtained their doctorates in economics at the University of Chicago. 
Marshallian-Friedmanian marriage market models are comparable to partial equilibrium models of labor markets and need prices in order to clear. His optimal assignments lead to markets that can possibly clear with the help of a price mechanism, but not necessarily so. A marriage market equilibrium means different things, depending on whether one analyzes marriage with Friedmanian price theory or not.

Becker's application of demand and supply analysis to marriage is part of the tradition started by his mentors, Milton Friedman in particular. Becker's optimal sorting models are optimal assignment models that were not particularly popular in any field of economics in the 1970s. Two possible explanations for their inclusion in Becker's theory of marriage is that Becker was familiar with such models from the time he was a student at Chicago, and that he was sensitive to the interests of sociologists. In the sections on optimal sorting, Becker refers to similar models by Koopmans and Beckmann. All three economists were at Chicago in the early 1950s. The topic of optimal sorting has also been popular among sociologists of marriage, and marriage has traditionally been a topic of interest to sociologists more than economists.

It is shown that Becker's students who used models of marriage were inspired by Becker's Friedmanian approach more than by his optimal assignment approach. Research on intra-household distribution in the 1980s and 1990s seems to have overlooked some of the relevant ideas that Becker's theory of marriage contains on this topic.

More research on Becker's theory of marriage and its evolution is needed, including analyses comparing Becker (1973) and (1981) with the chapter on marriage in Becker and Murphy (2000). A topic for further research is the role of gender in the 1973 and 1981 versions of Becker's theory of marriage.

More generally, it is hoped that this research on Becker's theory of marriage will contribute to future research on Chicago Price Theory. It is particularly interesting to compare the evolution of various fields of economics that are part of the expansion of economics and associated with the work of Becker and other Chicago economics, including a comparison of law and economics and the economics of marriage.

\section{REFERENCES}

Apps, Patricia F. and Ray Rees. 1988. "Taxation and the Household." Journal of Public Economics 35:355-369.

Becker, Gary S. 1960. "An Economic Analysis of Fertility." In Demographic and Economic Change in Developed Countries, a Conference of the Universities--National Bureau Committee for Economic Research. Princeton, N.J.: Princeton University Press.

. 1964. Human Capital. New York: Columbia University Press.

. 1965. "A Theory of Allocation of Time.” Economic Journal 75:493-515.

. 1973. "A Theory of Marriage: Part I." Journal of Political Economy 81:813-846.

. 1974. "A Theory of Marriage: Part II." Journal of Political Economy 82:511-26. 
Press.

. 1976a. The Economic Approach to Human Behavior. Chicago: University of Chicago

. 1976b. "Prefatory Note to Special Issue about Gregg Lewis". Journal of Political

Economy 84 (4): S1.

. 1981. A Treatise on the Family. Cambridge: Harvard University Press, first edition.

.1991a. A Treatise on the Family. Cambridge: Harvard University Press, second edition.

. 1991b. "Milton Friedman," in Remembering the University of Chicago: Teachers, Scientists

and Scholars, ed by Edward Shils, Chicago: U of Chicago Press, pp. 138-146

. 1992. "Autobiography." http://www.nobel.se/economics/laureates/1992/becker-

autobio.html.

1993. Private conversation with this author in Anaheim, California, January.

2004. Personal communication by email, October 12 .

. 2006. “On Milton Friedman's Ideas.” The Becker/Posner blog. http://www.becker-

posner-blog.com/archives/2006/11/on_milton_fried.html

. 2007. "Introduction to the Transaction Edition." Economic Theory. New Brunswick:

Aldine Transaction, second edition.

Becker, Gary S. and H. Gregg Lewis. 1973. "On the Interaction between the Quantity and Quality of Children.” Journal of Political Economy 81(2, pt. 2): S279-S288.

Becker, Gary S., Elizabeth Landes, and Robert Michael. 1977. "An Economic Analysis of Marital Instability." Journal of Political Economy 85: 1141-88.

Becker, Gary S. and Kevin M. Murphy. 2000. Social Economics. Market Behavior in a Social Environment. Cambridge, Mass: Belknap/Harvard University Press.

Botticini, Maristella and Aloysius Siow. 2003. "Why Dowries?” American Economic Review 93: 1385-98.

Bourguignon, Francois and Pierre-Andre Chiappori. 1992. "Collective Models of Household Behaviour : an Introduction" European Economic Review 36:355-65.

Bronfenbrenner, Martin. 1971. "A Note on the Economics of the Marriage Market." Journal of Political Economy 79:1424-25.

Clignet, Remi and Joyce Sween. 1977. "On Grossbard's Economic Analysis of Polygyny in Maiduguri." Current Anthropology 18:100. 
Deaton, Angus S., Javier Ruiz-Castillo, and Duncan Thomas. 1989. “The Influence of Household Composition on Household Expenditure Patterns: Theory and Spanish Evidence" Journal of Political Economy 97:179-200.

Emmett, Ross B. 2007. "Sharpening Tools in the Workshop: the Workshop System and the Chicago School's Success." Paper presented at Conference on the Chicago School of Economics, Notre Dame University, September.

Freiden, Alan. 1972. "A Model of Marriage and Fertility." Ph.D. dissertation, University of Chicago.

Freiden, Alan. 1974. "The U.S. Marriage Market." In Economics of the Family, edited by T.W. Schultz. Chicago: University of Chicago Press.

Friedman, Milton. 1976 (originally, 1962). Price Theory. New York: Aldine de Gruyter.

Fuchs, Victor R. 1994. “Nobel Laureate Gary Becker: Ideas about Facts.” Journal of Economic Perspectives 8:183-192.

Gale, David and Lloyd S. Shapley. 1962. "College Admissions and the Stability of Marriage." American Mathematical Monthly 69:9-15.

Gronau, Reuben. 1970. "An Economic Approach to Marriage: the Intra-family Allocation of Time." Paper presented at the Second World Congress of the Econometric Society, Cambridge, U.K.

Grossbard, Amyra. 1976. "An Economic Analysis of Polygamy: The Case of Maiduguri." Current Anthropology 17:701-7.

. 1978a. "Towards a Marriage Between Economics and Anthropology and a General Theory of Marriage." American Economic Review 68:33-37. . 1978b. "The Economics of Polygamy." Ph.D. Dissertation, University of Chicago.

Grossbard, Shoshana Amyra and Catalina Amuedo-Dorantes. 2007. "Marriage Markets and Women's Labor Force Participation.” Review of Economics of the Household 5:249-278.

Grossbard-Shechtman, Amyra. 1984. "A Theory of Allocation of Time in Markets for Labor and Marriage." Economic Journal 94:863-82.

Grossbard-Shechtman, Shoshana A. 1993. On the Economics of Marriage. Boulder, CO: Westview Press.

. 2001. "The New Home Economics at Columbia and Chicago." Feminist Economics $7(3): 103-130$.

Heer, David M. and Amyra Grossbard-Shechtman. 1981. "The Impact of the Female Marriage Squeeze and the Contraceptive Revolution on Sex Roles and the Women's 
Liberation Movement in the United States, 1960 to 1975." Journal of Marriage and the Family 43(1):49-65.

Hildenbrand, Werner. 1982. "Core of an Economy." in Handbook of Mathematical Economics Vol 2, edited by Kenneth Arrow and Michael D. Intriligator. Rotterdam: Northholland/Elsevier, pp. 831-877.

Hoddinott, John and Lawrence Haddad. 1995. "'Does Female Income Share Influence Household Expenditures: Evidence from the Cote d' Ivoire” Oxford Bulletin of Economics and Statistics 57:77-96

Keeley, Michael C. 1974. "A Model of Marital Information: The Determinants of the Optimal Age at First Marriage and Differences in Age At Marriage." Ph.D. Dissertation, University of Chicago.

Keeley, Michael C. 1977. “The Economics of Family Formation.” Economic Inquiry 25:238250.

Koopmans, Tjalling C. and Martin Beckman. 1957. "Assignment Problems and the Location of Economic Activities.” Econometrica 25: 53-76.

Landes, Elizabeth. 1978. “The Economics of Alimony.” Journal of Legal Studies 1: 35-63.

Lazear, Edward P. 2000. “Economic Imperialism.” Quarterly Journal of Economics 115:99-146.

Lemennicier, Bertrand. 1980. "La Spécialisation des Rôles Conjugaux, les Gains du Mariage et la Perspective du Divorce." Consommation 1:27-71.

1988. Le Marche du Mariage et de la Famille. Paris: Presses Universitaires de France.

Lundberg, Shelly and Robert A. Pollak. 1993. "Separate Sphere Bargaining and the Marriage Market.” Journal of Political Economy 101:988-1010.

Manser, Marilyn and Murray Brown. 1980. "Marriage and Household Decision Making: a Bargaining Analysis." International Economic Review 21:31-44.

McElroy, Marjorie B. 2006. Personal communication by email, January 18.

McElroy, Marjorie B. and Mary Jane Horney. 1981. "Nash Bargained Household Decisions: Toward a Generalization of the Theory of Demand." International Economic Review 22:33349.

Medema, Steven G. 2007. "Introduction." in Milton Friedman, Price Theory, New Brunswick, NJ: Aldine-Transaction.

. 2008. "Chicago Price Theory and Chicago Law and Economics." Ms, University of Colorado, Denver, September. 
Mincer, Jacob. 2006. "Acceptance Speech upon Receiving the First IZA Prize." In Shoshana Grossbard, ed., Jacob Mincer: a Pioneer of Modern Labor Economics. New York: Springer.

Papps, Ivy. 1983. "The Role and Determinants of Bride Price: the Case of a Palestinian Village." Current Anthropology 24: 203.

Peters, Elizabeth H. 1986. "Marriage and Divorce: Informational Constraints and Private Contracting," American Economic Review 76:437-54.

Pickford-Santos, Fredericka. 1970. "Marital Instability and Male-Female Complementarity." Ph. D. Dissertation, Columbia University.

Pollak, Robert A. 2003. "Gary Becker's Contributions to Family and Household Economics." Review of Economics of the Household 1(1): 111-141.

Rao, Vijayendra. 1993. "The Rising Price of Husbands: A Hedonic Analysis of Dowry Increases in Rural India." Journal of Political Economy 101(4):666-677.

Reder, Melvin W. 1982. "Chicago Economics: Permanence and Change.” Journal of Economic Literature 20:1-38.

Reid, Margaret R. 1934. Economics of Household Production. New York: Wiley.

Robbins, Lionel. 1962. The Nature and Significance of Economic Science. London: Macmillan.

Rosen, Sherwin. 1974. "Hedonic Prices and Implicit Markets: Product Differentiation in Pure Competition.” Journal of Political Economy 82: 34-55. . 1981. "The Economics of Superstars.” American Economic Review 71(5):845-858.

Schultz, T.W. 1974. Economics of the Family. Chicago: University of Chicago Press and NBER.

Shils, Edward, editor. 1991. Remembering the University of Chicago: Teachers, Scientists and Scholars. Chicago: U of Chicago Press.

Van Overtveldt, Johan. 2007. The Chicago School: How the University of Chicago Assembled the Thinkers Who Revolutionized Economics and Business. Chicago: Agate. 


\section{CESifo Working Paper Series}

for full list see www.cesifo-group.org/wp

(address: Poschingerstr. 5, 81679 Munich, Germany, office@cesifo.de)

2573 Jo Thori Lind, Karl Ove Moene and Fredrik Willumsen, Opium for the Masses? Conflict-Induced Narcotics Production in Afghanistan, March 2009

2574 Silvia Marchesi, Laura Sabani and Axel Dreher, Agency and Communication in IMF Conditional Lending: Theory and Empirical Evidence, March 2009

2575 Carlo Altavilla and Matteo Ciccarelli, The Effects of Monetary Policy on Unemployment Dynamics under Model Uncertainty - Evidence from the US and the Euro Area, March 2009

2576 Falko Fecht, Kjell G. Nyborg and Jörg Rocholl, The Price of Liquidity: Bank Characteristics and Market Conditions, March 2009

2577 Giorgio Bellettini and Filippo Taddei, Real Estate Prices and the Importance of Bequest Taxation, March 2009

2578 Annette Bergemann and Regina T. Riphahn, Female Labor Supply and Parental Leave Benefits - The Causal Effect of Paying Higher Transfers for a Shorter Period of Time, March 2009

2579 Thomas Eichner and Rüdiger Pethig, EU-Type Carbon Emissions Trade and the Distributional Impact of Overlapping Emissions Taxes, March 2009

2580 Antonios Antypas, Guglielmo Maria Caporale, Nikolaos Kourogenis and Nikitas Pittis, Selectivity, Market Timing and the Morningstar Star-Rating System, March 2009

2581 António Afonso and Christophe Rault, Bootstrap Panel Granger-Causality between Government Budget and External Deficits for the EU, March 2009

2582 Bernd Süssmuth, Malte Heyne and Wolfgang Maennig, Induced Civic Pride and Integration, March 2009

2583 Martin Peitz and Markus Reisinger, Indirect Taxation in Vertical Oligopoly, March 2009

2584 Petra M. Geraats, Trends in Monetary Policy Transparency, March 2009

2585 Johannes Abeler, Armin Falk, Lorenz Götte and David Huffman, Reference Points and Effort Provision, March 2009

2586 Wolfram F. Richter, Taxing Education in Ramsey’s Tradition, March 2009

2587 Yin-Wong Cheung, Menzie D. Chinn and Eiji Fujii, China's Current Account and Exchange Rate, March 2009 
2588 Alexander Haupt and Silke Uebelmesser, Voting on Labour-Market Integration and Education Policy when Citizens Differ in Mobility and Ability, March 2009

2589 Hans Jarle Kind, Marko Koethenbuerger and Guttorm Schjelderup, Should UtilityReducing Media Advertising be Taxed?, March 2009

2590 Alessandro Cigno, How to Avoid a Pension Crisis: A Question of Intelligent System Design, March 2009

2591 Helmut Lütkepohl and Fang Xu, The Role of the Log Transformation in Forecasting Economic Variables, March 2009

2592 Rainald Borck, Hyun-Ju Koh and Michael Pflüger, Inefficient Lock-in and Subsidy Competition, March 2009

2593 Paolo M. Panteghini, On the Equivalence between Labor and Consumption Taxation, March 2009

2594 Bruno S. Frey, Economists in the PITS?, March 2009

2595 Natalie Chen and Dennis Novy, International Trade Integration: A Disaggregated Approach, March 2009

2596 Frédérique Bec and Christian Gollier, Term Structure and Cyclicity of Value-at-Risk: Consequences for the Solvency Capital Requirement, March 2009

2597 Carsten Eckel, International Trade and Retailing, March 2009

2598 Gianni De Nicolò and Iryna Ivaschenko, Global Liquidity, Risk Premiums and Growth Opportunities, March 2009

2599 Jay Pil Choi and Heiko Gerlach, International Antitrust Enforcement and Multi-Market Contact, March 2009

2600 Massimo Bordignon and Guido Tabellini, Moderating Political Extremism: Single Round vs Runoff Elections under Plurality Rule, April 2009

2601 Ana B. Ania and Andreas Wagener, The Open Method of Coordination (OMC) as an Evolutionary Learning Process, April 2009

2602 Simon Gächter, Daniele Nosenzo, Elke Renner and Martin Sefton, Sequential versus Simultaneous Contributions to Public Goods: Experimental Evidence, April 2009

2603 Philippe Jehiel and Andrew Lilico, Smoking Today and Stopping Tomorrow: A Limited Foresight Perspective, April 2009

2604 Andreas Knabe, Steffen Rätzel, Ronnie Schöb and Joachim Weimann, Dissatisfied with Life, but Having a Good Day: Time-Use and Well-Being of the Unemployed, April 2009 
2605 David Bartolini and Raffaella Santolini, Fiscal Rules and the Opportunistic Behaviour of the Incumbent Politician: Evidence from Italian Municipalities, April 2009

2606 Erkki Koskela and Jan König, Can Profit Sharing Lower Flexible Outsourcing? A Note, April 2009

2607 Michel Beine, Frédéric Docquier and Çağlar Özden, Diasporas, April 2009

2608 Gerd Ronning and Hans Schneeweiss, Panel Regression with Random Noise, April 2009

2609 Adam S. Booij, Bernard M.S. van Praag and Gijs van de Kuilen, A Parametric Analysis of Prospect Theory's Functionals for the General Population, April 2009

2610 Jeffrey R. Brown, Julia Lynn Coronado and Don Fullerton, Is Social Security Part of the Social Safety Net?, April 2009

2611 Ali Bayar and Bram Smeets, Economic, Political and Institutional Determinants of Budget Deficits in the European Union, April 2009

2612 Balázs Égert, The Impact of Monetary and Commodity Fundamentals, Macro News and Central Bank Communication on the Exchange Rate: Evidence from South Africa, April 2009

2613 Michael Melvin, Christian Saborowski, Michael Sager and Mark P. Taylor, Bank of England Interest Rate Announcements and the Foreign Exchange Market, April 2009

2614 Marie-Louise Leroux, Pierre Pestieau and Gregory Ponthiere, Should we Subsidize Longevity?, April 2009

2615 Ronald MacDonald, Lukas Menkhoff and Rafael R. Rebitzky, Exchange Rate Forecasters' Performance: Evidence of Skill?, April 2009

2616 Frederick van der Ploeg and Steven Poelhekke, The Volatility Curse: Revisiting the Paradox of Plenty, April 2009

2617 Axel Dreher, Peter Nunnenkamp, Hannes Öhler and Johannes Weisser, Acting Autonomously or Mimicking the State and Peers? A Panel Tobit Analysis of Financial Dependence and Aid Allocation by Swiss NGOs, April 2009

2618 Guglielmo Maria Caporale, Roman Matousek and Chris Stewart, Rating Assignments: Lessons from International Banks, April 2009

2619 Paul Belleflamme and Martin Peitz, Asymmetric Information and Overinvestment in Quality, April 2009

2620 Thomas Dohmen, Armin Falk, David Huffman and Uwe Sunde, Are Risk Aversion and Impatience Related to Cognitive Ability?, April 2009 
2621 Yin-Wong Cheung and Xingwang Qian, The Empirics of China's Outward Direct Investment, April 2009

2622 Frédérique Bec and Christian Gollier, Assets Returns Volatility and Investment Horizon: The French Case, April 2009

2623 Ronnie Schöb and Marcel Thum, Asymmetric Information Renders Minimum Wages Less Harmful, April 2009

2624 Martin Ruf and Alfons J. Weichenrieder, The Taxation of Passive Foreign Investment Lessons from German Experience, April 2009

2625 Yao Li, Borders and Distance in Knowledge Spillovers: Dying over Time or Dying with Age? - Evidence from Patent Citations, April 2009

2626 Jim Malley and Ulrich Woitek, Technology Shocks and Aggregate Fluctuations in an Estimated Hybrid RBC Model, April 2009

2627 Jin Cao and Gerhard Illing, Endogenous Systemic Liquidity Risk, April 2009

2628 Thiess Buettner and Bjoern Kauder, Revenue Forecasting Practices: Differences across Countries and Consequences for Forecasting Performance, April 2009

2629 Håkan Selin, The Rise in Female Employment and the Role of Tax Incentives - An Empirical Analysis of the Swedish Individual Tax Reform of 1971, April 2009

2630 Nick Johnstone and Ivan Hascic, Environmental Policy Design and the Fragmentation of International Markets for Innovation, April 2009

2631 Spiros Bougheas, Richard Kneller and Raymond Riezman, Optimal Education Policies and Comparative Advantage, April 2009

2632 Jay Pil Choi and Heiko Gerlach, Multi-Market Collusion with Demand Linkages and Antitrust Enforcement, April 2009

2633 Thor O. Thoresen, Income Mobility of Owners of Small Businesses when Boundaries between Occupations are Vague, April 2009

2634 Guido Schwerdt and Amelie C. Wuppermann, Is Traditional Teaching really all that Bad? A Within-Student Between-Subject Approach, April 2009

2635 Kurt R. Brekke, Luigi Siciliani and Odd Rune Straume, Hospital Competition and Quality with Regulated Prices, April 2009

2636 Peter Diamond, Taxes and Pensions, April 2009

2637 Shoshana Grossbard, How "Chicagoan” are Gary Becker's Economic Models of Marriage?, May 2009 